\title{
Geo-Structural Nonlinear Analysis of Piles for Performance Based Design
}

\author{
M. Hesham El Naggar, Mehdi Heidari \\ Western University \\ 1151 Richmond St., London, Canada \\ naggar@uwo.ca; msarvest@uwo.ca
}

\begin{abstract}
Pile foundations supporting bridge structures are often subjected to static and/or dynamic lateral loads due to different hazards such as vessel impacts, traffic, waves, wind, and earthquakes. Two major factors that affect the pile lateral behavior under extreme lateral loading are the interaction between the pile and surrounding soil and the material inelasticity of the pile itself. This presentation covers the state-of-the-art of modeling the nonlinear response of piles. In addition, it describes the recent development of an efficient and robust approach for the analysis of piles based on the Beam on Nonlinear Winkler (BNWF). In this work, a general cyclic BNWF model is developed to account for the important features of soil-pile interaction problem including lateral load characteristics, soil cave-in, soil-pile side shear, gap formation, and strength and stiffness hardening/degradation. The inelastic behavior of pile material is also modeled effectively by implementing the advanced fiber technique. The capability of the developed model in predicting the response of pile under lateral static and cyclic loading is validated by comparing the computed results with experimental data.
\end{abstract}

Keywords: Piles, Performance Based Design, Nonlinear, Lateral Response, Bridge Foundations, Extended Shafts.

\section{Introduction}

Buildings and bridge structures supported on pile foundations are subjected to lateral loads and moments due to earthquakes, wind, lateral earth pressure and traffic. For an economical and safe design of piles subjected to static and cyclic lateral loading, the nonlinear soil behavior and pile material nonlinearity should be accounted for in the analysis. Different approaches are used for analysis of pile response under extreme lateral loading conditions, ranging from sophisticated finite element analysis to simplified beam on nonlinear Winkler foundation (BNWF) models. The latter approach is widely used in practice for the nonlinear analyses of piles due to its computational simplicity, reasonable accuracy and extensive experience in practical applications (Ashford and Juirnarongrit 2006; Brandenberg et al. 2007; Chiou, 2009). In these simplified models, the soil resistance is simulated by employing a series of unconnected nonlinear springs, whose stiffness is characterized by soil resistance-deflection curves that are known as p-y curves. The p-y curves can also be used as the backbone curve of BNWF models utilized for analysis of pile response to cyclic lateral loads. The main drawback of this method is that it does not account properly for soil continuity and pile properties such as shape of cross-section and head conditions. The accuracy of $p-y$ curve analysis depends upon the proper characterization of $p-y$ curve to consider the soil-pile interaction.

The inelastic response of soil-pile system also depends on the pile's material behavior in the nonlinear range of deformation as well as nonlinear soil-pile interaction. Two types of element formulation are possible for incorporating material nonlinearity: lumped plasticity and distributed plasticity. In the lumped plasticity model, the element is simulated by two zero length plastic hinges in the form of nonlinear springs located at the ends of elastic element (Clough and Benuska 1967, Filippou and Issa 1988). In the distributed plasticity model, the element cross-section is subdivided into fibers, where the material nonlinearity can occur anywhere along the element. The fiber model can be utilized to analyze the nonlinear behavior of beam-column elements. Employing this technique, the pile element behavior is derived by using weighted integration of the section response allowing the nonlinearity to occur at any section along the pile element. Thus, 
the fiber model for beam-column elements combines accurate description of the section behavior with the simplicity of a frame element (Filippou et al. 1988).

\section{Literature Review}

\subsection{Piles Response to Static Loading}

There are two main simplified approaches that can be used to simulate the nonlinear response of piles to static lateral loads, p-y curve approach and the strain wedge model.

Figure 1a demonstrates the concept of using p-y curves to simulate the soil resistance, $p$, to pile deflection, $y$, under lateral loading. The spring force-deformation relationship represented by the p-y curves can be obtained from results of lateral load tests on instrumented piles. The procedure to construct the p-y curves is illustrated in Figure 1b. The distribution of pile bending moment can be established based on the pile curvature obtained from the strain gauge data along the pile. The soil reaction and pile deflection along the pile can then be determined by double and fourth integration of the bending moment, respectively, and the variation of soil resistance with pile deflection, i.e. p-y curve, can be assessed at any given depth. This process is given by Equation 1, i.e.

$$
p(z)=\frac{d^{2} M(z)}{d z^{2}} \text { and } y_{\text {pile }}(z)=\iint \frac{M(z)}{E_{p} I_{p}} d z
$$

Where $M(z)$ is the pile bending moment at depth $\mathrm{z}$; and $E_{p}, I_{p}$ are the elastic modulus of pile material and its crosssectional moment of inertia.
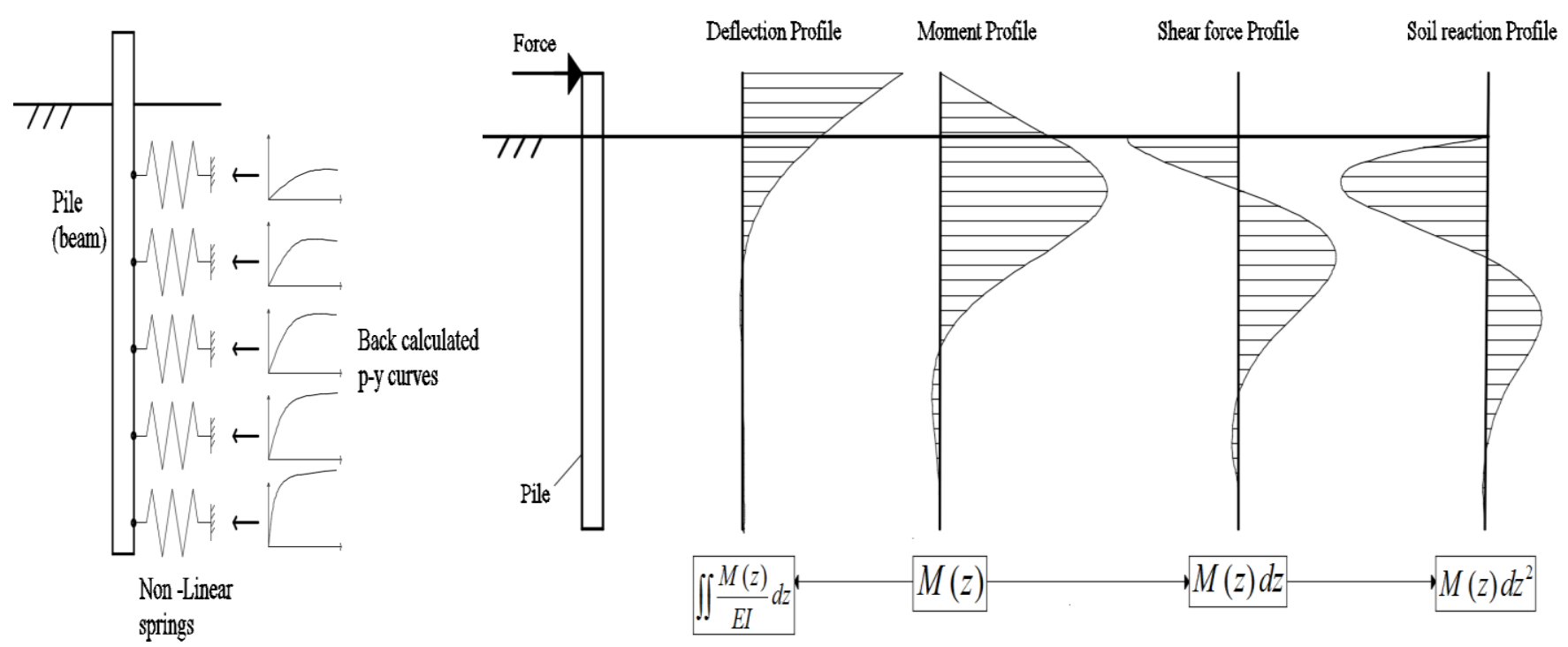

Fig. 1: Pile lateral response analysis using p-y curves: a) typical model; b) methodology for developing $\mathrm{p}$ and y profile.

Different formulations have been proposed to develop p-y curves for various soil types based upon full-scale test results (e.g. McClelland and Focht 1958; Matlock 1970; Reese et al. 1975; Welch and Reese 1972; Cox et al. 1974; Murchison and O'Neill 1984). McClelland and Focht (1956) established a direct relationship between the experimental p-y curves and the stress-strain properties of the clay. Matlock (1970) developed a procedure for predicting p-y curves in soft submerged clay deposits based on results of tests on fully instrumented flexible pipe piles. The field testing was carried out at two sites: Lake Austin and Sabine. Reese and Welch (1975) proposed criteria for predicting the behavior of flexible piles in stiff clays above the water table. The field tests were performed on a drilled shaft, but the developed criteria is assumed to be applicable to most deep foundations. Reese et al. (1974) developed a semi-empirical expression for p-y curves for 
sand based on the results of the Mustang Island tests. The ultimate soil resistance near the ground surface was developed based on a wedge type failure theory. The selection of adequate p-y curves is the most crucial problem when using this methodology for the analysis of laterally loaded piles (Reese and Van Impe, 2001). Although the empirical p-y curve relationships have been supported by field tests, the accuracy of analysis is sensitive to the suitability of implemented p-y curves. The behavior of laterally loaded pile is influenced by pile type, flexural stiffness, shape, cap conditions and installation method as well as type of loading (monotonic or cyclic). These important factors represent intrinsic characteristics of the developed p-y curves and their effects are difficult to separate due to the limited number of full-scale tests (Juirnarongrit and Ashford, 2005).

The strain wedge (SW) model predicts the nonlinear pile response accounting for the realistic conditions of the soilpile system (Ashour and Norris, 2000). The main concept of SW model is that the soil resistance in the one-dimensional models can be characterized in terms of a three-dimensional soil-pile interaction behavior. In this way, the generated p-y curves incorporate both soil and pile properties based on the 3D soil-pile interaction. The SW model evaluates the mobilized passive wedge in front of the deflected pile in order to account for the pile-soil interaction considering soil continuity (Reese et al.1975; Ashour et al. 1998, 2004; Ashour and Norris 2000; Lianget al. 2007; Shatnawi 2008). The mobilized passive soil wedge is related to the slip plane directions during the mobilization of inter-particles friction angle $(\varphi)$ for a pile in sand, and the observed displacement field around a laterally loaded pile as seen in experiments (Hughes et al. 1978). The three-dimensional passive wedge for a particular value of lateral strain, $\varepsilon$, in the soil in front of the deflected pile is characterized by the mobilized base angle, $\beta_{\mathrm{m}}$, the current passive wedge depth, $\mathrm{h}$, (related to the current depth of "zero crossing," i.e., $y=0$, of the pile) and the spread of the wedge fan angle, $\varphi_{\mathrm{m}}$, (the mobilized friction angle) as shown in Figure 2.

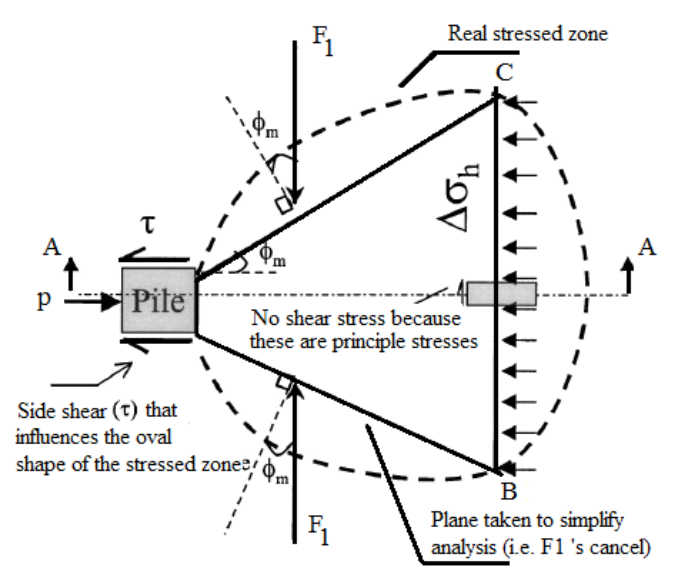

b) Force equilibrium in a slice of the wedge at depth $x$

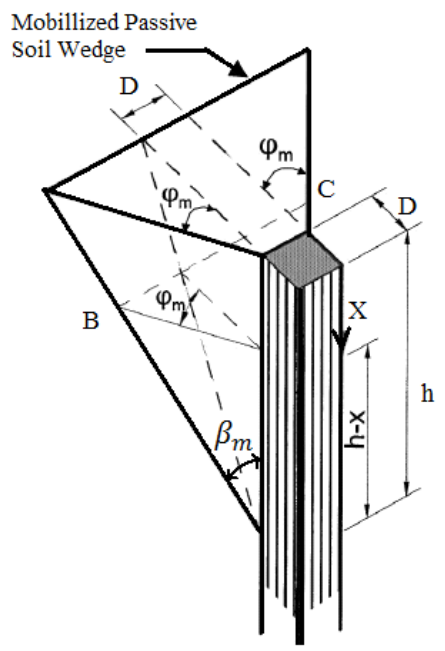

a) Basic Strain Wedge (SW) Model

Fig. 2: Basic strain wedge in uniform soil (Ashour et al. 2004).

The configuration of the developed passive wedge at any instant of load is given by:

$$
\beta_{m}=45+\frac{\varphi_{m}}{2} \quad \text { and } \quad \overline{B C}=d+(h-x) 2 \tan \beta_{m} \tan \varphi_{m}
$$

where $\overline{B C}$ is the width of wedge face at depth $\mathrm{x}$ from the ground surface and $\mathrm{d}$ is the pile diameter.

In the SW model, the horizontal soil stress change $\left(\Delta \sigma_{\mathrm{h}}\right)$ associated with the lateral soil strain $(\varepsilon)$ within the passive wedge in front of the deflected pile is related to the soil-pile reaction (p). The equilibrium of horizontal and shear stresses for the horizontal slice of the passive wedge at depth $\mathrm{x}$ is expressed as 


$$
p=\bar{S}_{1} \overline{B C}\left(\Delta \sigma_{h}\right)+2 \bar{S}_{2} D \tau
$$

where $\mathrm{p}$ is the force per unit length of the pile, $\Delta \sigma_{\mathrm{h}}$ is the major principal stress change in the direction of pile movement, $\tau$ is the mobilized pile side shear stress, and $\bar{S}_{1}$ and $\bar{S}_{2}$ are pile shape factors which equal 0.75 and 0.5 , respectively, for a circular pile cross section, and 1.0 for a square pile (Ashour et al. 1998). The strain wedge model utilizes the concept of beam on elastic foundation (BEF) to satisfy the global stability conditions. For sand soil, the SW model analysis utilizes basic soil parameters such as the angle of internal friction, $\varphi$, effective unit weight, $\bar{\gamma}$, and void ratio, e, whereas the other parameters such as soil strain at $50 \%$ of stress level, $\varepsilon_{50}$, can be estimated using available correlations. In the case of clay, the undrained shear strength, $S_{u}$, and plasticity Index, PI, are the governing properties in the SW model analysis, which are correlated to the effective angle of internal friction, $\bar{\varphi}$, and $\varepsilon_{50}$.

The p-y curve derived based on the SW model incorporates both soil and pile properties accounting for the threedimensional soil-pile interaction behavior. It should be noted that the active soil pressure at the back of the pile is not incorporated in the SW model and the resultant soil reaction, p, is only assessed based on the developed passive wedge in front of the pile. The SW model described by Ashour et al. (1998) is not capable of accounting for the gapping and soil cave-in occurred in the cyclic response analysis of laterally loaded pile. Nonetheless, the strain wedge model is employed to derive the p-y curve, which is then implemented as the backbone curve of the beam on nonlinear Winkler foundation model.

\subsection{Piles Response to Cyclic Loading}

Different beam on nonlinear Winkler foundation (BNWF) models were proposed to analyze the pile lateral response under cyclic loading. Most BNWF models are developed as stand-alone programs and can be used for modeling specific types of problems. Some of the models have also been developed with commercial software. However, most of them are not capable to appropriately account for certain cyclic/dynamic response features of laterally loaded pile. Matlock and his co-workers performed several cyclic field and laboratory pile lateral load tests and the results were used to develop a beamon-dynamic-Winkler-foundation formulation that was incorporated in the analysis program SPASM 8 (Matlock and Foo 1978). In this model, a discrete element linear elastic pile was linked to a fully nonlinear, hysteretic, degrading soil support model. The gapping capability was accounted for in the model by simulating the foundation system as two series of detachable Winkler springs on either side of the pile. A parallel array of elasto-plastic sub-elements and linear dashpots were attached directly to the pile to account for the nonlinear hysteretic behavior and radiation damping in the analysis. Soil degradation was also provided as a penalty method, incurred as an element experienced a full reversal in the direction of slip, with the ultimate resistance asymptotically approaching a specified lower bound. It is noted that the model employed nonlinear springs near to the ground surface and elastic springs at lower depths (due to the anticipating elastic response in this zone) to provide computational efficiency.

Consequently, several researchers developed different BNWF models for the lateral response analysis of piles accounting for soil nonlinearity, gap opening at the soil-pile interface, and energy dissipation through both material and geometric damping (El Naggar and Novak, 1996a; Pender and Pranjoto, 1996; El Naggar and Bentley, 2000; Boulanger et al. 1999; Moustafa and El Naggar, 2002; Gazetas and gerolymos, 2005).

Allotey and El Naggar (2008a, b) developed a generalized dynamic BNWF model as shown in Figure 3. The model accounted for various important soil-structure interaction (SSI) features such as soil and pile nonlinear behavior, cyclic hardening/degradation, soil cave in and gap formation, and nonlinear radiation damping. The stiffness and strength degradation factors for variable-amplitude loading condition were evaluated using a cyclic counting method. The developed BNWF model was successfully employed in the publicly available software SeismoStruct to study the response of piles. The model accounted for various main response features and was backbone-curve independent. However, the effect of pile characteristics on the lateral response was not incorporated in the analysis. Heidari et al. (2014a and b) extended the model to incorporate the 3-dimensional interaction response of laterally loaded pile in different types of soils. In this approach, the SW model based p-y curve was implemented as the backbone curve of the developed BNWF model to study the nonlinear response of single pile under cyclic lateral loading. As shown in Figure 4, the model was compression-dominant, which involves two spring elements at each depth for modeling pile-soil interaction. The combined response of the two springs should be the same as the original backbone curve. However, horizontal leftward shift of the force-displacement curve to model prestraining effect would lead to different response during the initial gap formation. 
The other issue is that the estimation of model parameters is largely based on intuition, without any particular supporting theory or experimental evidence. These models were used to evaluate the response of different structures subjected to extreme loading conditions due to earthquakes, wind, current and wave loading or ground movement (e.g. El Naggar and Novak, 1996b; Mostafa and El Naggar, 2004 and 2006; El Naggar, et al., 2005). All the above BNWF models assume that the pile behaves in a linear elastic manner, or utilizes equivalent linear analysis to account for the nonlinearity of the pile material.

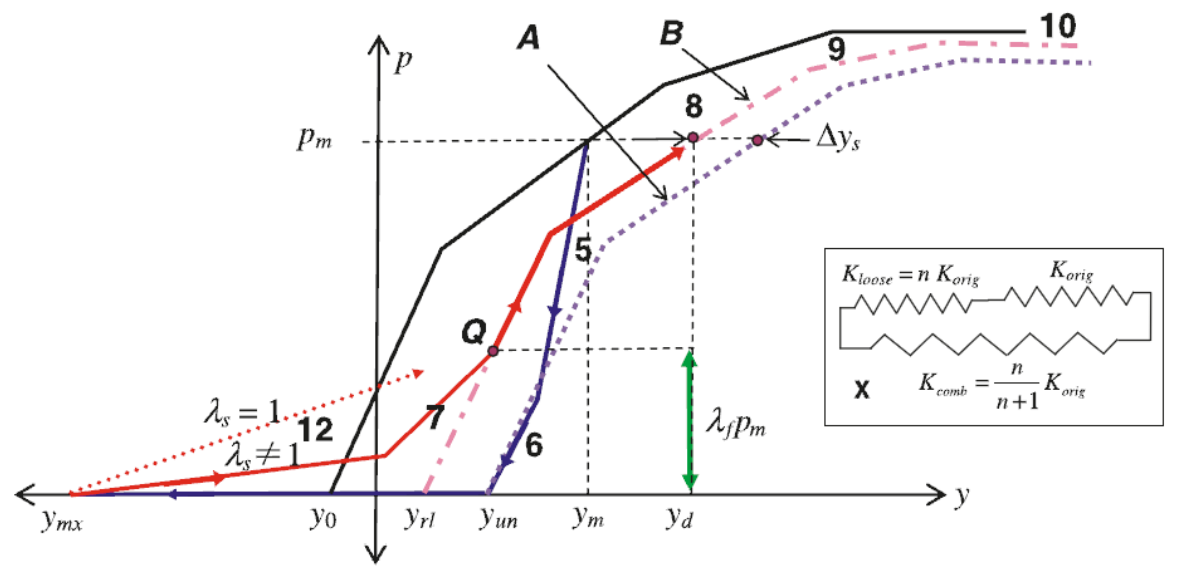

Fig. 3: Schematic of dynamic BNWF model (Allotey and El Naggar 2008b).

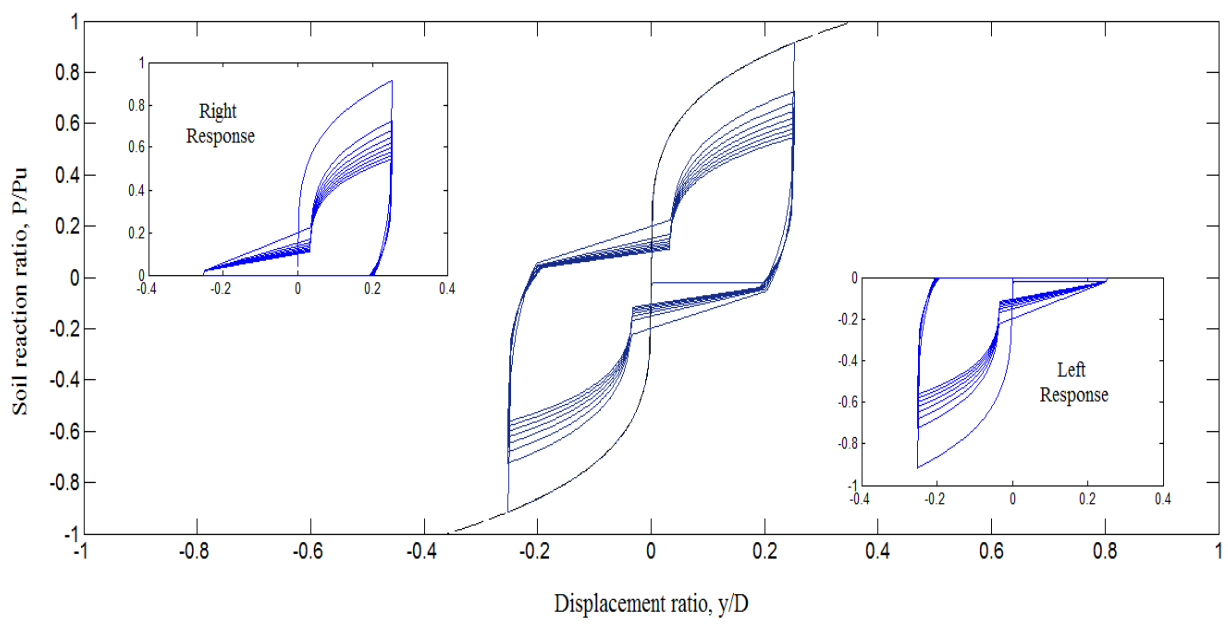

Fig. 4: Response of a two-spring system to two-way cyclic loading (heidari et al. 2013).

\section{Geo-structural Nonlinear Analysis of Piles}

To perform truly nonlinear analysis of pile shafts under lateral loading, the fiber technique is used. In this technique, the pile is subdivided into sufficient number of 2D beam-column elements, while the soil is replaced by sets of nonlinear springs along the pile length. The displacement field of each element is determined from the nodal displacements using interpolation functions along the element for the axial and transverse displacements. Figure 3.1 presents the element crosssection, subdivided into a number of fibers and its behavior is characterized by some monitoring cross-sections along the element. 

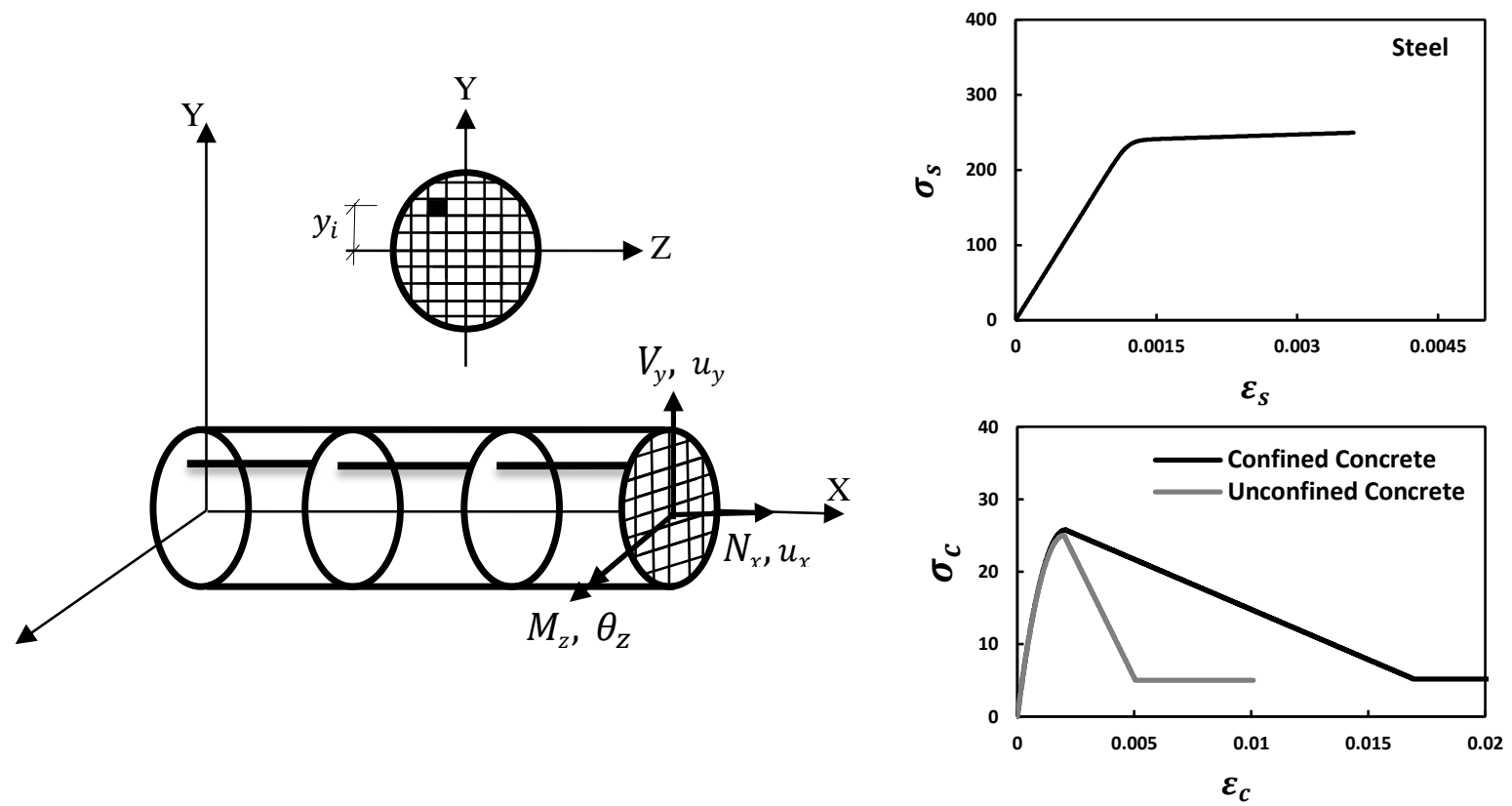

Fig. 5: An element with several monitoring sections subdivided into fibers.

In order to compute the strain of each fiber, it is assumed that the deformations are small and plane sections remain plane based on the Euler-Kirchhoff's hypothesis. The deformation vector, $\varepsilon_{s}(x)$, of each cross-section along the element is related to the element nodal displacement vector $\bar{d}_{e}$ and the strain for each controlling section is achieved from the related section deformation, i.e.

$$
\varepsilon_{S}(x)=\left\{\begin{array}{l}
\varepsilon_{x}(x) \\
\chi_{z}(x)
\end{array}\right\}=B_{d}(x) \cdot \bar{d}_{e} \quad \text { and } \quad \varepsilon_{f}(x)=l^{T} \cdot \varepsilon_{s}(x)
$$

where $\varepsilon_{\mathrm{x}}(\mathrm{x})$ is the axial strain, $\chi_{2}(\mathrm{x})$ is the curvature and $\mathrm{B}_{\mathrm{d}}(\mathrm{x})$ is the matrix obtained from the appropriate derivatives of the displacement shape functions and $l$ is a linear compatibility matrix as follow, i.e.

$$
l=\left[\begin{array}{ccccc}
1 & 1 & 1 & & 1 \\
-y_{1} & -y_{2} & -y_{3} & & -y_{N}
\end{array}\right]
$$

where $\mathrm{N}$ is the number of fibers for each section subdivision. The actual stress distribution across the cross-section is calculated using appropriate stress-strain relationship for the pile material. The constitutive relationship proposed by Filippou et al. (1983) for steel is used in the model to account for material nonlinearity and isotropic strain hardening. For reinforced concrete, the monotonic envelope curve is based on the model proposed by Kent and Park (1973) and Scott et al. (1982). The tensile strength of concrete is neglected since it has negligible influence on the behavior of RC section after cracking occurred. The calculated fiber stresses are integrated across the section to determine the section stress vector, $\sigma_{s}$, i.e.

$$
\sigma_{\mathrm{s}}(\mathrm{x})=\left\{\begin{array}{l}
\mathrm{N}_{\mathrm{x}}(\mathrm{x}) \\
\mathrm{M}_{\mathrm{z}}(\mathrm{x})
\end{array}\right\}=\sum_{\mathrm{f}} \mathrm{a} \cdot \sigma^{\mathrm{f}} \cdot \mathrm{A}^{\mathrm{f}}
$$

Where $\mathrm{N}_{\mathrm{x}}(\mathrm{x})$ and $\mathrm{M}_{\mathrm{z}}(\mathrm{x})$ are the axial force and bending moment about $\mathrm{z}$ axis, respectively, for the monitoring section located at $\mathrm{x}, \sigma^{f}$ is the fiber stress and $A^{f}$ is the corresponding area of each fiber. The internal element nodal force, $\bar{f}_{e}$, can be simply attained by implementing the principle of virtual work and weighted integration of the section response at the numerical integration points, defined by Gauss-Legendre quadrature rule, using the following relation 


$$
\bar{f}_{e}=\sum_{s} B_{d}(x)^{T} \cdot \sigma_{s}(x) \cdot w t_{s}
$$

where $\mathrm{wt}_{\mathrm{s}}$ is the weight coefficient associated with the Jacobian at the $\mathrm{s}^{\text {th }}$ section of the element. The stiffness matrix of each section can also be related to the fiber stiffness, $E^{f}$ and the distance, $\mathrm{y}$, from natural axis of the cross-section as shown in Figure 5. The element stiffness matrix can be calculated similarly by the following equation

$$
\bar{k}_{e}=\sum_{s} B_{d}(x)^{T} \cdot k_{s}(x) \cdot B_{d}(x) \cdot w t_{s}
$$

This process for determining the internal nodal forces corresponding to the element nodal displacements comprises three phases: section, element and structure state determination. At the structure level, the element stiffness matrices and internal element force vectors are assembled to form the augmented stiffness matrix, $\mathrm{K}$, and internal nodal force vector, $F^{\text {int }}$. An iterative solution method is required to reduce the residual force vector (the difference of total applied external force vector and internal nodal force vector) until equilibrium is satisfied within a specified tolerance in the following equation

$$
\left\{\begin{array}{l}
F_{t} \\
F_{u}
\end{array}\right\}=\left[\begin{array}{l}
K_{t t} \\
K_{t u} \\
K_{u t} K_{u u}
\end{array}\right]\left\{\begin{array}{l}
u_{t} \\
u_{u}
\end{array}\right\}
$$

where subscript $\mathrm{t}$ and $\mathrm{u}$ are related to free end constrained degrees of freedom, respectively. In this study, NewtonRaphson method is used for the analysis of pile response when subjected to force-controlled or displacement-controlled loading.

Different features of pile-soil interaction are simulated by replacing surrounding soil with a series of nonlinear springs attached at both sides along the pile length. The soil model used in GSNAP is compression-dominant, which consists of two spring elements at each depth allowing simulation of gap formation and pile-soil separation (Heidari and El Naggar 2017).

\section{Verification}

Several case histories of lateral load tests on full-scale instrumented piles are analysed using the developed software GSNAP, which is developed based on the theories described above. The cases analysed cover a range of pile configurations and materials installed in different types of soils.

\section{Case 1: Steel pipe pile in clay}

Matlock (1970) reported results from full-scale lateral load tests of steel pipe pile with an outside diameter of $0.324 \mathrm{~m}$ and a wall thickness of $12.7 \mathrm{~mm}$. The load was applied to the free-head pile at $0.06 \mathrm{~m}$ above the mudline. The pile was driven into slightly overconsolidated clays and silt with average undrained shear strength, $S_{u}=38.3 \mathrm{kPa}$. An average value of $\varepsilon_{50}=0.012$ was estimated from laboratory testing and submerged unit weight was found to be almost constant with depth with average value of $10 \mathrm{kN} / \mathrm{m}^{3}$. Figures $6 \mathrm{a}$ and $6 \mathrm{~b}$ compare the calculated and measured pile-head load versus deflection and pile-head load versus maximum bending moment curves. In Figure 6 (and the following figures), the red dashed lines represent yield bending moment, $\mathrm{M}_{\mathrm{y}}$, or the corresponding lateral load and/or deflection. As shown, the calculated and measured responses are in good agreement over a wide range of loading. The variation of bending moment with depth for different lateral pile-head loads is shown in Figure 6.c. The results demonstrate that the nonlinear model successfully predicted the shape of moment distribution curve observed in experiment for load equal to $80.9 \mathrm{kN}$. The nonlinear model predicted that yield bending moment would occur at the normalized depth of 10d below the ground surface for an applied lateral load of $148 \mathrm{kN}$. 


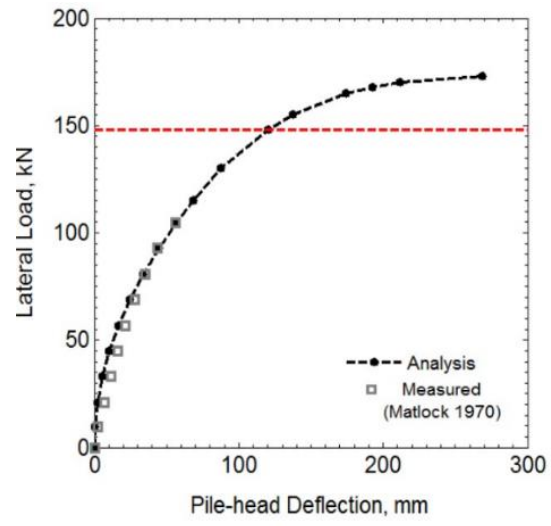

(a)

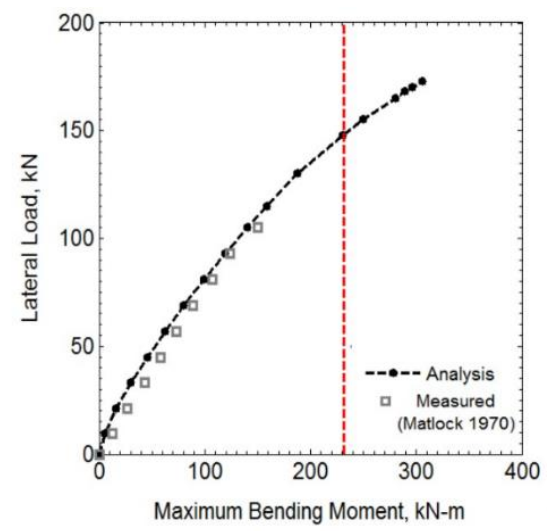

(b)

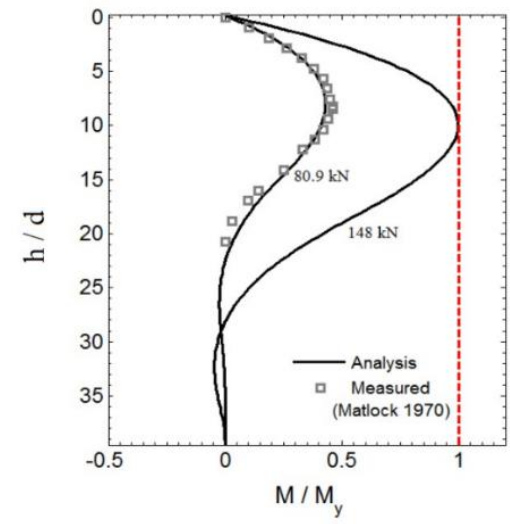

(c)

Fig. 6: Comparison of the measured and calculated pile response for case 1: a) Lateral load-deflection;

b) Lateral load-maximum moment; and c) normalized moment distribution for different applied load value.

\section{Case 2: Steel pipe pile in sand}

Cox et al. (1974) described a testing program involving a steel pipe pile with an outside diameter of $0.61 \mathrm{~m}$ and wall thickness of $9.5 \mathrm{~mm}$. The bending moment corresponding to the first yield was $640 \mathrm{kN}-\mathrm{m}$, and the bending moment for the formation of full plastic hinge was $828 \mathrm{kN}-\mathrm{m}$. The lateral load was applied at $0.305 \mathrm{~m}$ above the ground surface. The soil was uniformly graded fine sand with submerged unit weight of $10.4 \mathrm{kN} / \mathrm{m}^{3}$ and friction angle of $39^{\circ}$. The subgrade reaction modulus is estimated from correlation with friction angle as $16.3 \mathrm{kN} / \mathrm{m}^{3}$. Figure 7 shows good agreement between the calculated and measured responses. It is noted from Figure 7 that pile yielding significantly amplified the nonlinearity of the soil-pile system. The normalized depth corresponding to first yielding is approximately $4.1 \mathrm{~d}$ and the yield moment of pile cross-section is attained at lateral load of $326.5 \mathrm{kN}$.

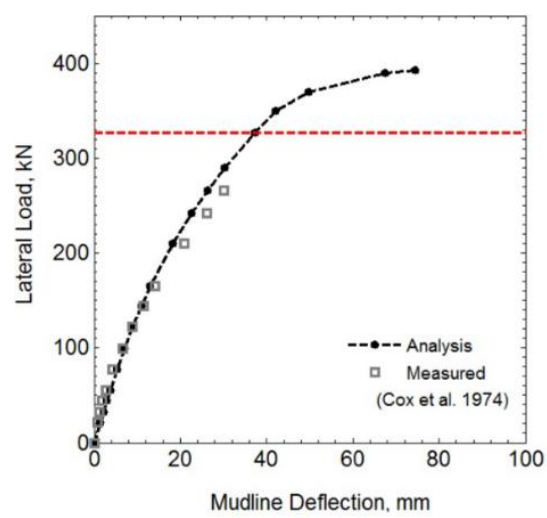

(a)

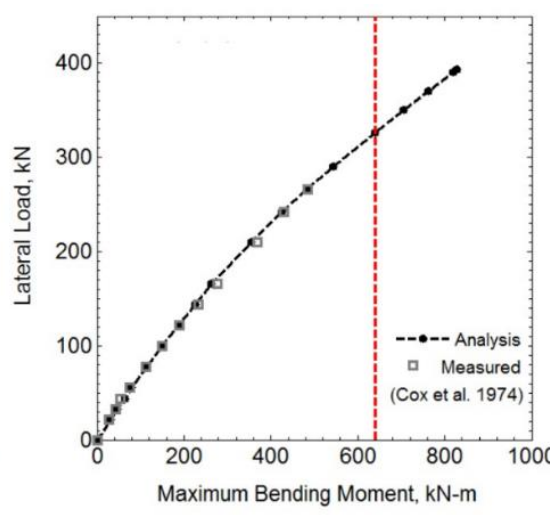

(b)

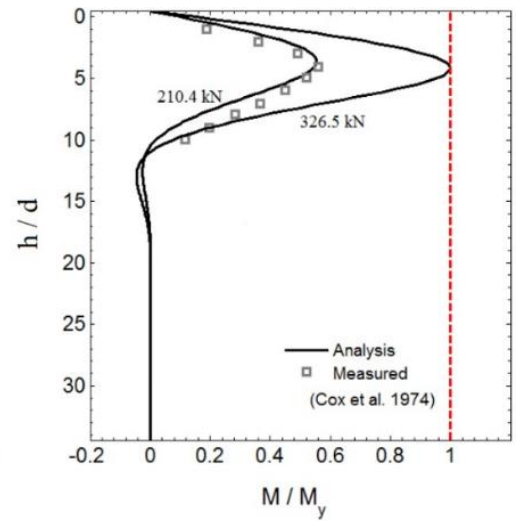

(c)

Fig. 7: Comparison of the measured and calculated pile response for case 2: a) Lateral load-deflection, b) Lateral load-maximum moment and c) normalized moment distribution for different applied load value.

\section{Case 3 and 4: Steel pipe pile in multi-layer soil}

Snyder (2004) conducted a series of lateral load tests on steel pipe piles at a site in Salt Lake City, Utah. The pile had outer diameter of $324 \mathrm{~mm}$ and wall thickness of $9.5 \mathrm{~mm}$. The pile was driven closed-ended to an embedment depth of 11.6 $\mathrm{m}$, with $2.1 \mathrm{~m}$ protruding above ground. The lateral load was applied at $495 \mathrm{~mm}$ above the ground line. The soil profile consisted of layers of soft to medium clay underlain by interbedded layers of sands and fine-grained soils. The soil properties were determined from field and laboratory tests. The same model parameters suggested by Snyder (2004) as presented in Table 1 are employed in the present analysis. Walsh (2005) conducted experimental field tests in the same site whereas the upper $0.91 \mathrm{~m}$ of clay layers were removed and replaced with washed concrete sand. 
Table 1: Soil parameters to model the pile test for Case 3 (Snyder 2004).

\begin{tabular}{|c|c|c|c|c|c|c|}
\hline depth (m) & Soil type & $\gamma^{\prime}\left(\mathrm{kN} / \mathrm{m}^{3}\right)$ & $\mathrm{S}_{\mathrm{u}}\left(\mathrm{kN} / \mathrm{m}^{2}\right)$ & $\phi\left(^{\circ}\right)$ & $\mathrm{k}\left(\mathrm{MN} / \mathrm{m}^{3}\right)$ & $\varepsilon_{50}$ \\
\hline $0-1.2$ & Clay & 9.05 & 41.4 & --- & ---- & 0.01 \\
\hline $1.2-2.1$ & Clay & 9.05 & 50 & --- & ---- & 0.01 \\
\hline 2.1-3.1 & Clay & 9.05 & 40 & -- & ---- & 0.01 \\
\hline 3.1-4.8 & Sand & 8.14 & ---- & 38 & 25.5 & - --- \\
\hline 4.8-5.3 & Clay & 9.05 & 56.9 & -- & ---- & 0.01 \\
\hline 5.3-5.9 & Clay & 9.05 & 25 & --- & ---- & 0.01 \\
\hline $5.9-6.5$ & Clay & 9.05 & 54 & --- & ---- & 0.01 \\
\hline 6.5-16.1 & Sand & 8.14 & ---- & 33 & 14.9 & ---- \\
\hline
\end{tabular}

The model parameters established by Walsh (2005) for different soil layers are used in the current analysis, as shown in Table 2. The pile was loaded at $0.483 \mathrm{~m}$ above the ground level, with different target deflections. Because the lateral behavior of pile is mostly controlled by soil characteristics along the top 5 to $10 \mathrm{~d}$ of the soil profile, the results from these two cases could provide insights into lateral response of piles embedded in sand versus clay.

Table 2: Soil parameters to model the pile test for: a) Case 3 (Snyder 2004); b) Case 4 (Walsh 2005).

\begin{tabular}{|l|l|l|l|l|c|l|}
\hline depth $(\mathrm{m})$ & Soil type & $\gamma^{\prime}\left(\mathrm{kN} / \mathrm{m}^{3}\right)$ & $\mathrm{S}_{\mathrm{u}}\left(\mathrm{kN} / \mathrm{m}^{2}\right)$ & $\phi\left(^{\circ}\right)$ & $\mathrm{k}\left(\mathrm{MN} / \mathrm{m}^{3}\right)$ & $\varepsilon \varepsilon_{50}$ \\
\hline $\mathbf{0 - 2 . 1}$ & Sand & 16.7 & ---- & 0 & 75 & ---- \\
\hline $\mathbf{2 . 1 - 2 . 4}$ & Sand & 6.8 & ---- & 0 & 42 & ---- \\
\hline $\mathbf{2 . 4 - 2 . 7}$ & Clay & 9.1 & 41 & --- & ---- & 0.01 \\
\hline $\mathbf{2 . 7 - 3 . 7}$ & Clay & 9.1 & 50 & --- & ---- & 0.01 \\
\hline $\mathbf{3 . 7 - 4 . 6}$ & Clay & 9.1 & 40 & --- & ---- & 0.01 \\
\hline $\mathbf{4 . 6 - 6 . 3}$ & Sand & 8.1 & ---- & 8 & 26 & ---- \\
\hline $\mathbf{6 . 3 - 8 . 0}$ & Clay & 9.1 & 57 & --- & ---- & 0.01 \\
\hline $\mathbf{8 . 0 - 1 6 . 1}$ & Sand & 6.7 & ---- & 3 & 150 & ---- \\
\hline
\end{tabular}

Figures $8 \mathrm{a}$ and $\mathrm{b}$ demonstrate that the calculated response agrees well with the measured response over a wide range of loading, and Figure 8c shows that the calculated depth of sections with zero and maximum negative bending moments are almost the same as those observed in the full-scale test. Figure 8c also reveals that the first yield of pile extreme fiber occurs at a depth 10d below the ground surface for applied pile-head deflection of $154 \mathrm{~mm}$. 


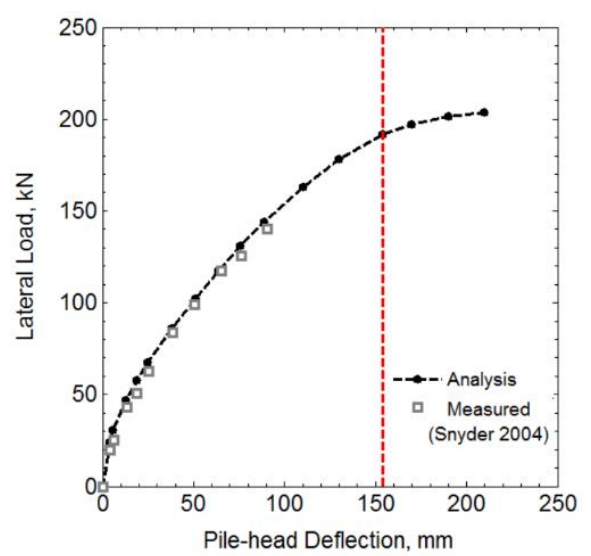

(a)

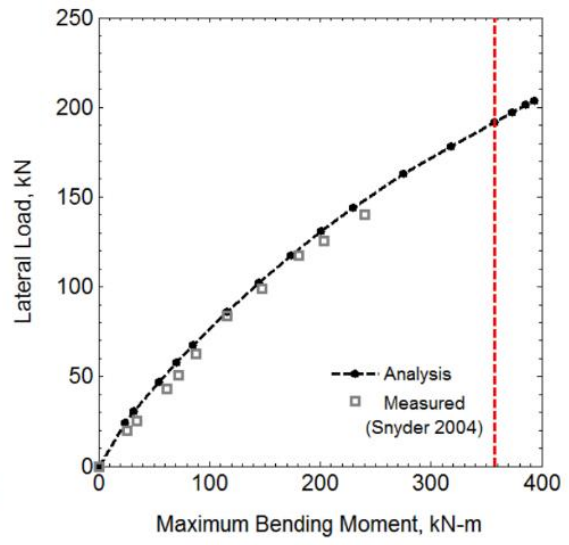

(b)

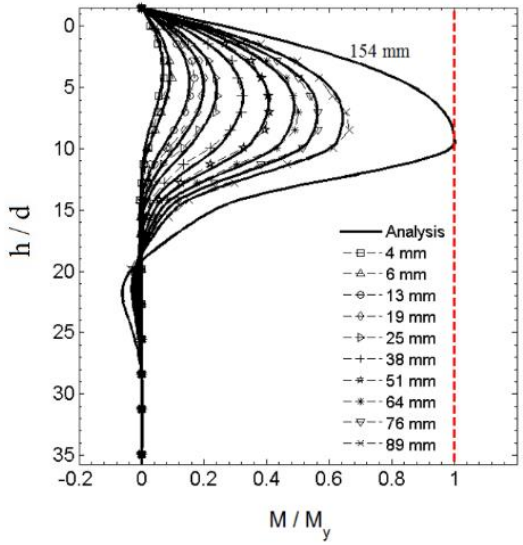

(c)

Fig. 8: Comparison of the measured and calculated pile response for case 3: a) Lateral load-deflection, b) Lateral load-maximum moment and c) normalized moment distribution for different target deflections.

Figure 9a demontrates the excellent agreement between the calculated and measured response in load tests (Welsh, 2005) for target deflections up to $25 \mathrm{~mm}$. For higher applied pile head deflection, the calculated lateral resistance is slightly lower than the measured one. Figure $9 \mathrm{~b}$ compares the calculated maximum bending moment with that derived from the strain gauge readings during the load tests. The agreement is excellent at low loading levels (up to $100 \mathrm{kN}$, which corresponds to $25 \mathrm{~mm}$ pile-head deflection), but the difference between the two sets increases as the loading increased with a maximum difference of about $15 \%$ at yield moment. It is important to note that during testing, both strain gages at depth of $1.84 \mathrm{~m}$ below ground surface malfunctioned at higher load levels and the bending moment data had to be interpolated based on the readings of the gages directly above and below the malfunctioning gages (Walsh 2005). This interpolation could possibly underestimate the maximum bending moment, especially at higher load levels where there was more drastic change in the values of bending moments within the depth of maximum moment. Although Walsh (2005) stated that the maximum developed bending moment was far enough below yielding moment, the observed and predicted responses shown in Figure 3.8a demonstrate that the maximum moment reached yield moment at a pile-head deflection between 76 and $89 \mathrm{~mm}$ (almost $83 \mathrm{~mm}$ ) as manifested by the excessive nonlinearity at this level of deflection. This excessive nonlinearity represents after-yield behavior as discussed in Case 2 (Cox et al., 1974). Figure 9c demonstrates reasonaable agreement between the calculated and measured normalized bending moment distribution with depth for different target deflections. However, the observed bending moments decreased more rapidly with depth than numerical predictions and the computed maximum negative moments are generally greater in magnitude than the measured values. This may be due to insufficient measured moment data to accurately assess moment distributions along the pile length at higher deflection levels. Also, the approximation of the soil model might have affected the computed bending moment distributions with depth. However, the nonlinear model was generally successful at predicting the response of laterally loaded pile embedded in multi-layered soil. 


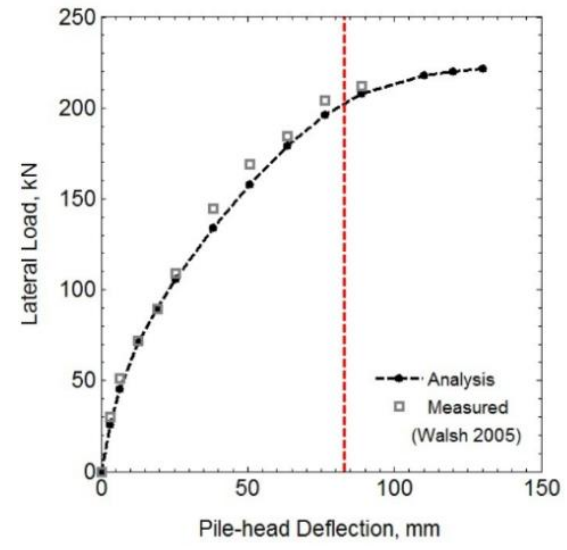

(a)

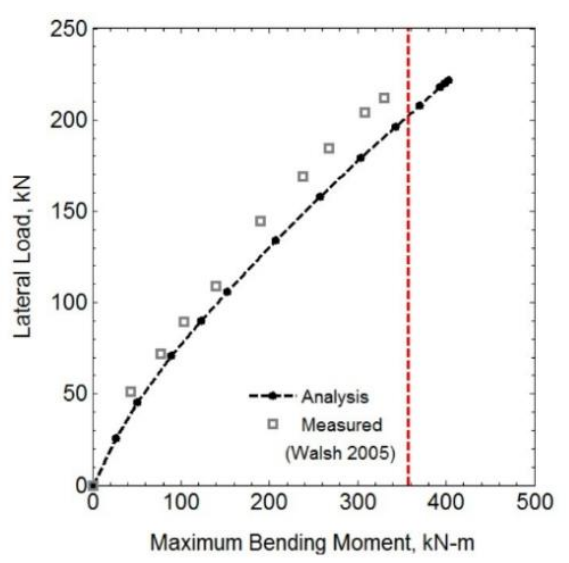

(b)

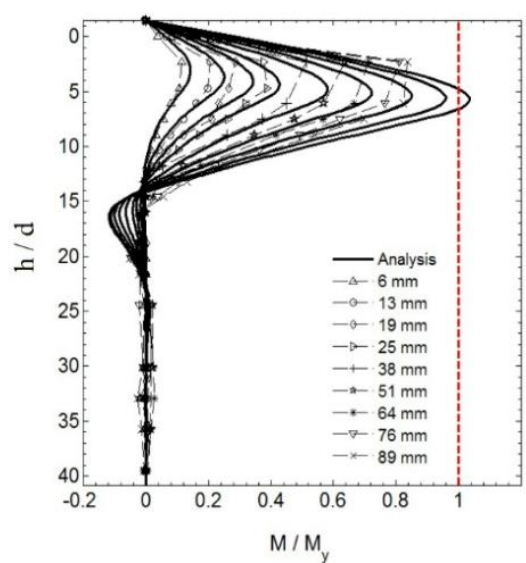

(c)

Fig. 9: Comparison of the measured and calculated pile response for case 3: a) Lateral load-deflection,

b) Lateral load-maximum moment and c) normalized moment distribution for different target deflections.

Comparing the results obtained from Walsh (2005) and Snyder (2004) in Figures 8 and 9, it is found that the yield bending moment of the pile with its upper part embedded in clay occurred at deflection $180 \%$ larger than that for pile its upper part embedded in sand. This is because the distribution of soil resistance, and consequently bending moment distribution, along the pile shaft is more uniform for pile embedded in clay than in sand. In addition, the maximum bending moment corresponding to first yield is predicted to occur at normalized depth of $5.5 \mathrm{~d}$ below the ground level for the pile tested by Walsh (2005), which is much shallower than for the pile installed in pure cohesive soil tested by Snyder (2004).

\section{Case 5: Steel $H$ pile in $c-\phi$ soil}

Mokwa (1997) performed lateral load tests on single 6 m long HP10x42 piles at Virginia Tech's Kentland Farms field test site. The soil profile consisted of sandy clay, sandy silt, and silty sand with thin layers of gravel. The soil engineering properties as determined by Mokwa (1999) are summarized in Table 3. The pile was embedded $5.03 \mathrm{~m}$ and was loaded at $0.457 \mathrm{~m}$ above the ground surface. The piles were tested using connections that partially restrained pile-head rotation. The rotational restraint coefficient, $\mathrm{k}_{\mathrm{m} \theta}$, was estimated based on best match with observed response through a trial and error process. The values obtained were 4.5 and $6.2 \mathrm{MN}-\mathrm{m} / \mathrm{rad}$ for matching load-deflection and load-rotation curves at the pilehead, respectively. The formulation developed by Mokwa and Duncan (2000) for soils with both cohesion and friction (c- $\phi$ soils) are used to construct p-y curves. Three pile head conditions are used in the analysis: free, partially restrained and fixed. For the restrained pile-head, the rotational restraint coefficient, $\mathrm{k}_{\mathrm{m} \theta}=4.2 \mathrm{MN}-\mathrm{m} / \mathrm{rad}$ is used.

Table 3: Soil parameters to develop p-y curve for case 5 (Mokwa 1999).

\begin{tabular}{|l|c|l|l|l|}
\hline depth $(\mathrm{m})$ & $\gamma^{\prime}(\mathrm{kN} / \mathrm{m} 3)$ & $S_{\mathrm{u}}(\mathrm{kN} / \mathrm{m} 2)$ & $\phi\left(^{\circ}\right)$ & $\varepsilon_{50}$ \\
\hline $\mathbf{0 - 0 . 8}$ & 19.1 & 48.3 & 38 & 0.01 \\
\hline $\mathbf{0 . 8 - 2 . 0}$ & 18.9 & 41.4 & 35 & 0.025 \\
\hline $\mathbf{2 . 0 - 2 . 3}$ & 18.5 & 34.5 & 28 & 0.025 \\
\hline $\mathbf{2 . 3 - 4 . 4}$ & 18.4 & 29.6 & 27 & 0.025 \\
\hline $\mathbf{4 . 4 - 4 . 7}$ & 17.7 & 27.6 & 25 & 0.025 \\
\hline $\mathbf{4 . 7 - 5 . 0}$ & 17.6 & 0 & 45 & 0.02 \\
\hline
\end{tabular}

Figures 10 compares the calculated and measured load-deflection and load-rotation response curves for different pilehead conditions. The calculated response considering pile-head rotational restraint of $4.2 \mathrm{MN}-\mathrm{m} / \mathrm{rad}$ agrees well with the measured response over a wide range of load values. As expected, the pile response for the partially restrained pile-head condition falls between the curves for fixed-head and free-head conditions; assuming free-head condition overestimated the 
response, while the fixed-head condition underestimated the response. For the partially restrained pile-head, however, first moment yield occurred at $38 \mathrm{~mm}$ pile head deflection, while it occurred at deflection of 10 and $31 \mathrm{~mm}$ for the fixed and free pile-head conditions, respectively. This can be explained by inspecting the normalized moment distribution presented in Figure 3.9.c. As can be noted from Figure 3.9.c, the maximum moment reached the yield moment at depth of 3.5d and $5 \mathrm{~d}$ below ground surface for the free and rotationally restrained pile-head condition, respectively. For the fixed head pile, the maximum moment value reached yield moment at the pile head. These observations indicate the important effect of pile-head rotational stiffness on its response to lateral loads.

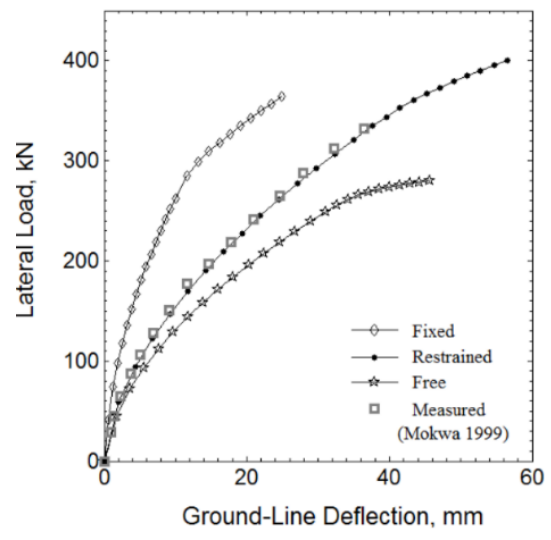

(a)

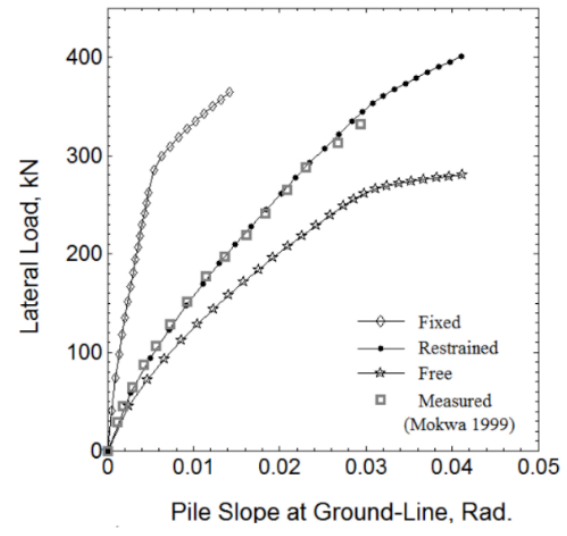

(b)

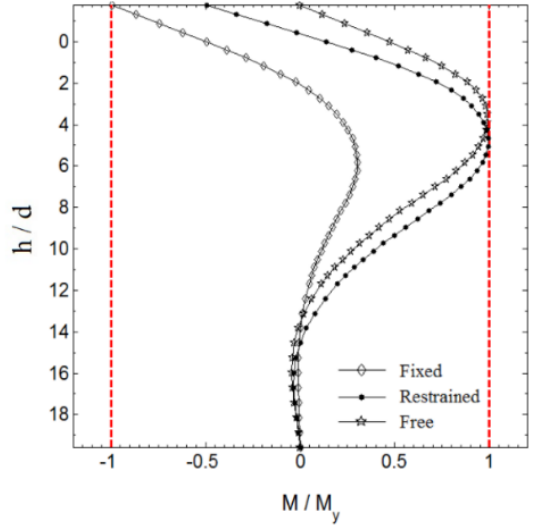

(c)

Fig. 10: Comparison of the measured and calculated pile response for case 5: a) Lateral load-deflection, b) Lateral load-slope and c) normalized moment distribution for different pile-head boundary conditions.

\section{Case 6: Reinforced concrete pile in sand}

Chai and Hutchinson (1999) conducted full-scale load tests on four reinforced concrete (RC) piles. The piles had a

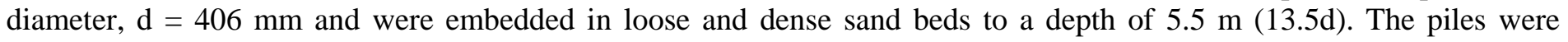
subjected to a combination of constant axial compression and reversed cyclic quasi-static lateral loading. The lateral load was applied at $2 \mathrm{~d}$ above ground for two piles and at $6 \mathrm{~d}$ for two piles. The concrete compressive strength $f_{c}^{\prime}$ was $41 \mathrm{MPa}$ for piles 1 and 2 and $47 \mathrm{MPa}$ for piles 3 and 4. The longitudinal reinforcement of each pile comprised 7 No. 22 bars (Grade A706) and the transverse reinforcement comprised a continuous spiral of MW25 or MW45 smooth wire at a $50 \mathrm{~mm}$ pitch. The analysis utilized a stress-strain relation for reinforced concrete in compression characterized the compressive strength of concrete and (longitudinal and transverse) reinforcement ratios. The strain hardening parameter of steel bars is assumed to be $0.5 \%$.

The sand friction angle, $\phi$, and relative density, $\mathrm{D}_{\mathrm{r}}$, were estimated using average normalized cone tip resistance measured in the upper 1 to 3 meters for each pile test. The unit weight of the sand was fairly uniform over the depth with an average value of 17 for piles 1 and 2 and $18.2 \mathrm{kN} / \mathrm{m}^{3}$ for piles 3 and 4 .Table 4 provides summary of soil and and pile properties as well as applied loads. The analyses are conducted without and with the inclusion of P- $\Delta$ effects. The initial subgrade reaction modulus for the p-y curve is selected to achieve the best-match of the calculated response with observed pile response accounting for P- $\Delta$ effects. Figure 11 compares the calculated and measured responses for the test piles. 
Table 4: Details of each RC pile test for case 6.

\begin{tabular}{|c|c|c|c|c|c|c|c|}
\hline $\begin{array}{l}\text { Pile test } \\
\mathrm{N} \\
\text { o. }\end{array}$ & $\begin{array}{l}\text { Soil } \\
\text { condition }\end{array}$ & $\begin{array}{c}\text { Above-ground } \\
\text { height }\end{array}$ & $\begin{array}{r}\text { Axial load } \\
\mathrm{kN}\end{array}$ & $\begin{array}{l}\text { Long. } \\
\text { Reinf. ratio }\end{array}$ & $\begin{array}{l}\text { Transv. } \\
\text { Reinf. } \\
\text { Ratio }\end{array}$ & $\begin{array}{c}\phi^{\prime} \\
\left.{ }^{\circ}\right)\end{array}$ & $\mathrm{N} / \mathrm{m}^{3}$ \\
\hline 1 & ose $^{\text {lo }}$ & $2 d$ & 445 & $2.1 \%$ & $\%$ & 7 & 2 \\
\hline 2 & nse $^{\text {de }}$ & $2 d$ & 490 & $2.1 \%$ & $\%^{0.57}$ & 4 & 5 \\
\hline 3 & ose $^{10}$ & $6 \mathrm{~d}$ & 445 & $2.1 \%$ & $\%^{1.06}$ & 8 & 2 \\
\hline 4 & nse $^{\text {de }}$ & $6 \mathrm{~d}$ & 445 & $2.1 \%$ & $\%^{1.06}$ & 2 & 0 \\
\hline
\end{tabular}

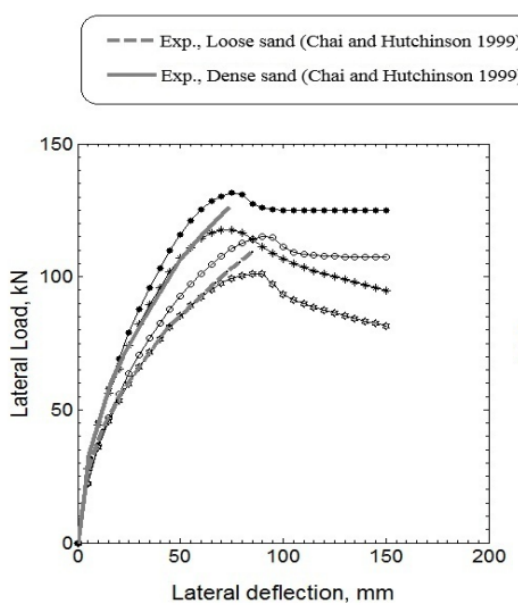

(a)

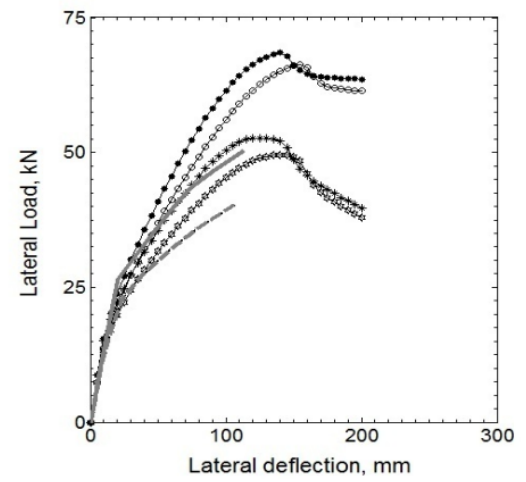

(d)

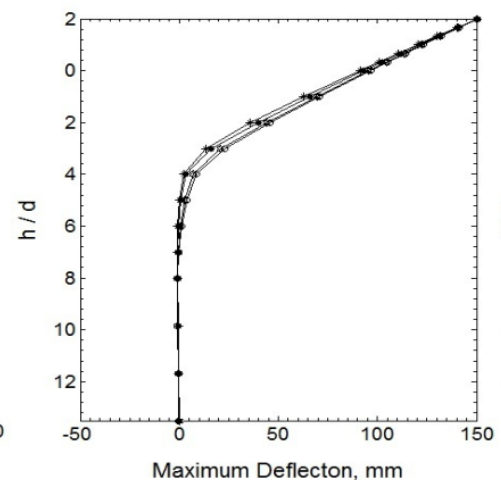

(b)
- Ana., Dense sand, Without P- $\Delta$ effect

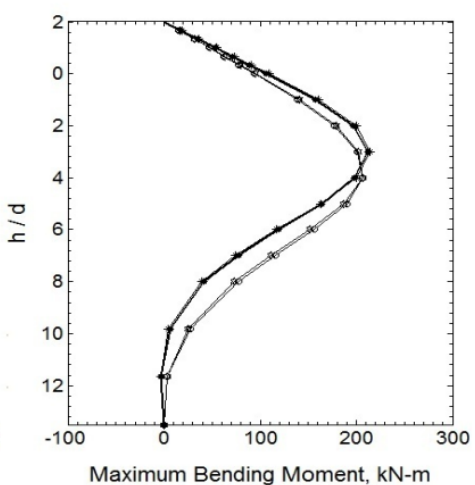

(c)

I. Test piles with an above-ground height of $2 \mathrm{~d}$

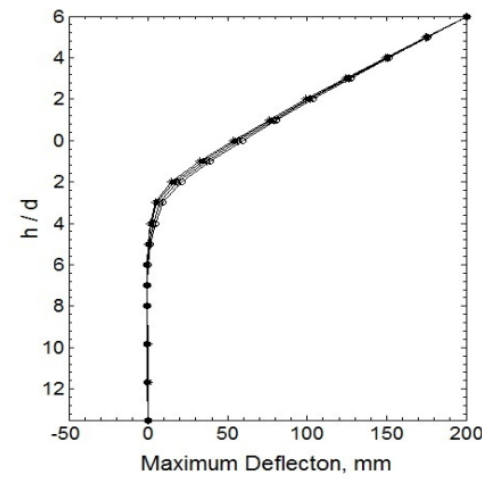

(e)

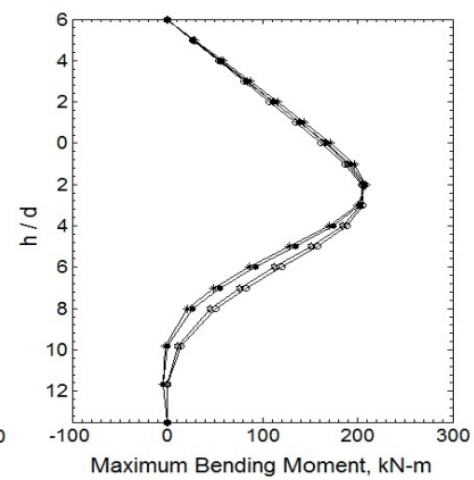

(f)

II. Test piles with an above-ground height of $6 \mathrm{~d}$

Fig. 11: Lateral load-deflection curves, maximum deflection and maximum bending moment profiles of case 6 with and without P- $\Delta$ effect for the test piles with above-ground height of: (I) 2D and (II) $6 \mathrm{D}$.

As can be noted from Figure 11, the calculated lateral load-deflection curves considering P- $\Delta$ effect are generally in excellent agreement with the observed response, with some minor discrepancy for pile test No.3 at defections higher than $50 \mathrm{~mm}$. As expected, the P- $\Delta$ effect caused additional bending moment and consequently larger lateral deflection for a given lateral load. Figures 3.10.c and f show that the maximum moment occurred at depth equal to $3 \mathrm{~d}$ and $4 \mathrm{~d}$ below ground 
surface for piles tested with $2 \mathrm{~d}$ free length embedded in loose sand and dense sand, respectively. For the piles tested with $6 \mathrm{~d}$ free length, the maximum moment occurred at depth equal to $2.6 \mathrm{~d}$ and $2 \mathrm{~d}$ below the ground surface for loose and dense sand, respectively. This means maximum moment for piles embedded in dense sand occurred at depth almost $25 \%$ shallower compared to those in loose sand.

\section{Cyclic BNWF Model}

A generalized BNWF model is developed for the analysis of piles under lateral cyclic loading to account for the salient features of pile-soil interaction. The developed BNWF model has four controlling parameters that facilitate simulating different nonlinear behaviour characteristics of soil. These parameters include: load characteristic factor, $\alpha_{1}$, limiting force factor, $\alpha_{\mathrm{f}}$, soil cave-in factor, $\alpha_{\mathrm{c}}$, and side-shear factor, $\alpha_{\mathrm{s}}$. The p-y curves are employed as the backbone curve of the soil model. The backbone curve is decomposed into two no-tension springs at each side of the pile by linearizing the initial part of the p-y curve and shifting the curve leftward as shown in Figure 12. The origin of the shifting distance, $\mathrm{y}_{0}$, is taken as a percentage of the deflection at one-half the ultimate soil resistance, y50, in such a way that the initial slope of the curve would be equal to the recommended value of subgrade reaction modulus. This distance also controls the gap depth and width during cyclic loading. The combined response of the two springs at each depth would lead to the same lateral behavior as that of a single p-y spring under monotonic loading, while allowing simulation of the gap opening and soil cave-in at soil-pile interface on each side, independently. The hysteresis cycle is capable of accounting for the maximum force experienced by the soil. Cyclic degradation and hardening mechanisms are also accounted for in the model by implementing a strength/stiffness degradation factor proposed by (Allotey and El Naggar, 2008c), i.e.:

$$
\delta=1+\left(\delta_{m}-1\right)\left[1-(1-D)^{\theta}\right]^{1 / \theta}
$$

Where $\delta_{\mathrm{m}}$ is the minimum or maximum value of strength/stiffness degradation, $\mathrm{D}$ is the currant cumulative damage and $\theta$ is a curve shape parameter. The rain flow cycle-counting method is used to determine the fatigue damage in variable amplitude loading. The S-N curve, which describes the cyclic stress ratio versus the number of loading cycles is used for damage calculation, with two possible forms (i.e.log-log and semi-log relations).

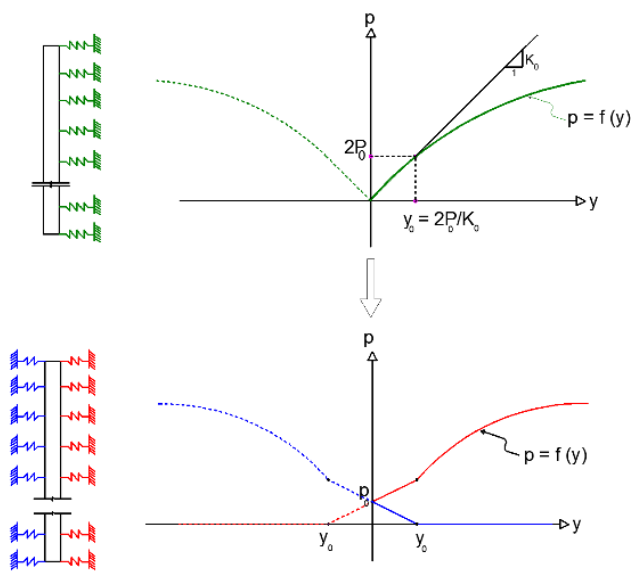

Fig. 10: Decomposition of the p-y spring element into two separate springs at each side of the pile.

This model was verified against several case studies of piles with different materials and installed in different soil types. The piles were subjected to cyclic lateral loading. The calculated results agreed well with the observed response.

\section{Conclusions}

The soil and pile nonlinear behavior could have significant effect on the lateral response of piles, especially at larger displacement level. Comparisons of experimental and calculated results revealed that the pile nonlinearity could be successfully accounted for in the analysis using the fiber beam-column elements that allow the development of plastic 
hinge at any depth along the pile. The soil nonlinearity could also be accounted for by simulating soil resistance employing a series of nonlinear load-transfer curves (i.e. p-y curves). The strain wedge model was used to develop p-y curves that can account for the effect of pile diameter and shape on the response of the pile at the local and global levels. A generalized BNWF model is developed to analyze the cyclic response of the pile, incorporating different important features of soilpile-interaction such as side shear effect, soil cave-in and gap formation, and soil degradation/hardening. It is observed that the soil cave-in could have a significant effect on the amount of residual deflection based on the soil type and hence, the corresponding BNWF model parameters should be selected carefully. Comparison of the measured and computed results reveals that the model can satisfactorily simulate the static and cyclic response of pile and accurately predict the nonlinear behavior of pile material.

\section{References}

[1] N. Allotey, M. El Naggar, "A Numerical study into lateral cyclic nonlinear soil-pile response," Canadian Geotechnical Journal, vol. 45, no. 9, pp. 1268-1281, 2008a.

[2] N. Allotey, M. El Naggar, "Generalized Dynamic Winkler model for nonlinear soil-structure interaction analysis," Canadian Geotechnical Journal, vol. 45, no. 4, pp. 560-573, 2008 b.

[3] N. Allotey, and M. H. El Naggar, "A consistent soil fatigue framework based on the number of equivalent cycles," Journal of Geotechnical and Geological Engineering, vol. 26, no. 1, pp. 65-77, 2008c.

[4] API, Recommended practice for planning, designing and constructing fixed offshore platforms-working stress design. API Recommended Practice 2A-WSD (RP 2A-WSD), 21 st edn, 1993.

[5] S. A. Ashford, T. Juirnarongrit, "Pushover Analyses of piles in laterally spreading soil," Geotechnical Special Publications (ASCE), GSP no. 145, pp. 109-120, 2005.

[6] M. Ashour, G. Norris, "Modeling Lateral Soil-Pile Response Based on Soil-Pile Interaction," Journal of Geotechnical and Geoenvironmental Engineering, ASCE, vol. 126, no. 5, pp. 420-428, 2000.

[7] M. Ashour, G. Norris, and P. Pilling, "Lateral Loading of a Pile in Layered Soil Using the Strain Wedge Model," Journal of Geotechnical and Geoenvironmental Engineering, ASCE, vol. 124, no. 4, pp. 303-315, 1998.

[8] Applied Technology Council ATC-32, Improved seismic design criteria for California bridges: provisional recommendations. Redwood City, California: ATC-32, 1996.

[9] S. J. Brandenberg, P. Singh, R. W. Boulanger, B. L. Kutter, "Behavior of piles in laterally spreading ground during earthquakes," Proc. 6th Caltrans Seismic Research Workshop, CA, paper 02-106, 2001.

[10] K. Brødbæk, M. Møller, S. Sørensen, \& A. Augustesen, Review of p-y relationships in cohesionless soil. DCE Technical Report No. 57, Aalborg University, Department of Civil Engineering, 2009.

[11] R. W. Boulanger, C. J. Curras, B. L. Kutter, D. W. Wilson, and A. Abghari, "Seismic soil-pile-structure interaction experiments and analyses," Journal of Geotechnical and Geoenvironmental Engineering, ASCE, vol. 125, no. 9, pp. 750-759, 1999.

[12] Y. Chai, T. Hutchinson, "Flexural strength and Ductility of extended pile-shafts-II: experimental study," ASCE Journal of structural Engineering, vol. 128, no. 5, pp. 595-602, 2002.

[13] J. Chiou, H. Yang, C. Chen, "Use of Plastic Hinge Model in Nonlinear Pushover Analysis of a Pile", J. Geotech. Geoenviron. Eng., vol. 135, no. 9, pp. 1341-1346, 2009.

[14] W. R. Cox, L. C. Reese, B. R. Grubbs, "Field testing of laterally loaded piles in sand," Proc. 6th Offshore Technology Conference, Paper 2079: Houston, Texas, pp. 459-472, 1974.

[15] F. Filippou, A. Issa, Nonlinear analysis of reinforced concrete frames under cyclic load reversals. Technical Report UCB/EERC-88/12: EERC, College of Engineering, University of California, Berkeley, 1988.

[16] F. Filippou, E. Popov, V. Bertero, of Bond Deterioration on Hysteretic Behavior of Reinforced Concrete Joints. Rep. No. UCB/EERC-83/19, Earthquake Engrg. Res. Ctr.: University of California, Berkeley, Calif, 1983.

[17] M. H. El Naggar, and K. J. Bentley, "Dynamic analysis for laterally loaded piles and dynamic p-y curves," Canadian Geotechnical Journal, vol. 37, no. 6, pp. 1166-1183, 2000.

[18] M. H. El Naggar, and M. Novak, "Nonlinear analysis for dynamic lateral pile response," J. of Soil Dynamics and Earthquake Engineering, vol. 15, no. 4, pp. 233-244, 1996a. 
[19] M. H. El Naggar, and M. Novak, "Influence of foundation nonlinearity on offshore towers response," $J$. of Geotechnical Engineering, ASCE, vol. 122, no. 9, pp. 717-724, 1996b.

[20] M. H. El Naggar, M. A. Shayanfar, M. Kimiaei, A. A. Aghakouchak, "Simplified BNWF model for nonlinear seismic response analysis of offshore piles," Canadian Geotechnical Journal, vol. 42, no. 2, pp. 365-380, 2005.

[21] M. Heidari, H. El Naggar, M. Jahanandish, A. Ghahramani, "Generalized cyclic p-y curve modeling for analysis of laterally loaded piles," Soil Dynamics and Earthquake Engineering, vol. 63, pp. 138-149, 2014a.

[22] M. Heidari, M. Jahanandish, H. El Naggar, A. Ghahramani, "Nonlinear cyclic behavior of laterally loaded pile in cohesive soil," Canadian Geotechnical Journal, vol. 51, no. 2, pp. 129-143, 2014b.

[23] A. Kampitsis, S. Giannakos, N. Gerolymos, E. Sapountzakis, "Soil-pile interaction considering structural yielding: Numerical modeling and experimental," Eng. Struct., vol. 99, pp. 319-333, 2015.

[24] D. Kent, R. Park, "Flexural Members with Confined Concrete," Journal of the Structural Division, ASCE, 97(ST7), 1971.

[25] H. Matlock, "Correlations for design of laterally loaded piles in soft clay," Proc. 2nd Offshore Technology Conference, Houston, vol. 1, pp. 577-594, 1970.

[26] H. Matlock, and S. Foo, "Simulation of lateral pile behavior under earthquake motion," Earthquake engineering and soil dynamics, Pasadena, CA, pp. 600-619, 1978.

[27] B. McClelland, J. Focth, "piles, Soil modulus for laterally loade," Trans., ASCE, 123, 1049-1063, 1958.

[28] M. Menegotto, P. Pinto, "Method of Analysis for Cyclically Loaded Reinforced Concrete Plane Frames Including Changes in Geometry and Non-Elastic Behavior of Elements," Proc.: IABSE Symp. on Resistance and Ultimate Deformability of Struct. Acted on by Well-Defined Repeated Loads, Lisbon, 1973.

[29] R. L. Mokwa, "Investigation of the resistance of pile caps to lateral loading," Ph.D. thesis, Virginia Polytechnic Institute and State University: Blacksburg, Va, 1999.

[30] R. L. Mokwa, J. M. Duncan, "Development of p - y curves for partly saturated silts and clays with both cohesion and friction," ASCE Geotechnical Special Publication (GSP No. 100), New Technological and Design Developments in Deep Foundations, GEO-Denver 2000, pp. 224-239, 2000.

[31] Y. E.Mostafa, El M. H. Naggar, "Dynamic analysis of laterally loaded pile groups in sand and clay," Canadian Geotechnical Journal, vol. 39, no. 6, pp. 1358-1383, 2002.

[32] Y. E. Mostafa, and El Naggar, "Effect of seabed instability on fixed offshore platforms," Soil Dynamics and Earthquake Engineering, vol. 26, pp. 1127-1142, 2006.

[33] Y. E. Mostafa, and El Naggar, "Response of fixed offshore platforms to wave and current loading including soilstructure interaction," Soil Dynamics and Earthquake Engineering, vol. 24, no. 4, pp. 357-368, 2004.

[34] J. Murchison, M. O'Neill, "Evaluation of p-y relationships in cohesionless soils: Analysis and Design of Pile Foundations," Proceedings of a Symposium in conjunction with the ASCE National Convention, pp. 174-191, 1984.

[35] M. Pender, Aseismic Foundation Design Analysis. Continuing Education Course, University of Auckland, NZ, 1995.

[36] L. C. Reese, W. F. Van Impe, Single Piles and Pile Group under Lateral Loading (2 ed.). Balkema, Rotterdam, 2001.

[37] L. C. Reese, W. R. Cox, R. D. Koop, "Analysis of Laterally Loaded Piles in Sand," Proceedings of the Sixth Annual Offshore Technology Conference, Houston, Texas, 2, paper no. OTC 2080, 1974.

[38] L. C. Reese, W. R. Cox, R. D. Koop, "Field Testing and Analysis of Laterally Loaded Piles in Stiff Clay," Proceedings of 7th Offshore Technology Conference, Houston, Texas, vol. II, pp. 473-483, 1975.

[39] B. Scott, R. Park, M. Priestley, "Stress-Strain Behavior of Concrete Confined by Overlapping Hoops at Low and High Strain Rates," ACI Journal, vol. 79, no. 1, pp. 13-27, 1982.

[40] K. Terzaghi, "Evaluation of coefficient of subgrade reaction," Geotechnique, vol. 5, no. 4, pp. 297-326, 1955.

[41] J. Walsh, "Full-Scale Lateral Load Test of a 3×5 Pile Group in Sand," M.Sc. thesis: Department of Civil and Environmental Engineering, Brigham Young University, UT, 2005.

[42] R. C. Welch, L. C. Reese, "Laterally loaded behavior of drilled shafts," Research Report 3-5-65-89: Center for Highway Research, University of Texas, Austin, 1972. 